\title{
Educational Supervision to Increase Teacher Professionalism in The 21st Century Learning Era
}

\author{
Tota Maria Nababan ${ }^{1 *}$, Sahara Ardani ${ }^{2}$, Sukarman Purba ${ }^{3}$ \\ ${ }^{1,2)}$ Post Graduate Education Management Universitas Negeri Medan, Indonesia \\ ${ }^{3)}$ Lecturer at Universitas Negeri Medan, Indonesia \\ *totamarianababan@gmail.com
}

\begin{abstract}
The development of information and communication technology so quickly has a very big influence in educational practice. The different characteristics of students and the learning environment that is far more advanced than in previous eras make education require teachers with different new indicators of professionalism. Educational institutions are expected to realize their role effectively, with excellence in leadership, teaching and learning processes, staff development, curriculum improvement, school goals, school climate or atmosphere, self-assessment and evaluation, communication activities, and the involvement of parents or the community. This research explores and discovers how educational supervision should be carried out in schools that are implementing new patterns in 21 st century learning. With these results it is hoped that they can contribute to improving teacher professionalism in accordance with the needs and development of schools today.
\end{abstract}

Keywords: education, supervision, professionalism, teacher

\section{Introduction}

Along with the advancement of time with the extraordinary development of technology and communication, and the increasingly rapid flow of communication, the world of education has changed a lot. In seconds and one touch, all forms of communication can be carried out, as if the world is so narrow. That is the development of the world community, which in fact has entered globalization, marked by the rapid information as a continuation of modern society, with its characteristics that are rational, future-oriented, open, respecting time, creative, independent, and innovative.

From this situation, the existence of a nation with other nations cannot be separated, as if to become one, both in the social, cultural, economic and so on. That is a picture of how things are in the 21 st century, a century of technological sophistication. As a human being, development cannot be avoided or even erased, but must be dealt with and responded to properly. Because the nature of technological progress to improve human welfare. The future that is full of excellence, will further affect the world of education both in terms of institutions, educational materials, teachers, methods, infrastructure and so forth. This is a challenge that must be answered by education. Education must be adapted to the development of the existing era, as well as teachers who have an important role in the world of education. The figure of the teacher is also adjusted to the needs of the times.

Education as the basis for a person's life in 'stepping' becomes something that is not free from change and technological development. The issue of education in the spotlight is about the quality of education that is always changing, with the development of civilization. 
Teachers as a profession are required to have professionalism in carrying out their profession. However, with the times that are increasingly changing towards advancing, and supported by technological advances, the figure of the teacher needed by the 21 st century is certainly different. Teachers are not only proficient in bringing their profession but also must be able to master a variety of tools and means of supporting technology in educational activities. Given the importance of the role of teachers in improving the quality of education, the study of the desired teacher figure in the 21 st century is very relevant. Everyone who cares about the world of education certainly wants the teacher to do the best for their students. The problem encountered in this research is how to supervise education that is optimal to be carried out in schools that are in line with 21 st century learning. It refers to the information that you have gotten on the rules of scientific writing.

In the 21 st century, the so-called digital era, is a challenge in the world of education. Educators/teachers are required to be creative and always update knowledge and follow technological developments. Principals as leaders must be able to run school programs and lead educators to be more active, creative and innovative in order to face the challenges of education in the digital age [1]. The author argues that "supervision contains several main activities, namely continuous coaching, professional capacity development of personnel, improvement of the teaching and learning situation, with the ultimate goal of achieving educational goals and the personal growth of learners".Supervision is an ongoing coaching activity with the aim of improving the situation of teaching and learning to improve the quality of education. This opinion is supported by Ari Sudibjo and Wasis [2] which agrees that "Supervision is not a momentary activity such as inspection, but it is a continuous and continuous activity so that teachers always develop in doing their tasks and are able to solve various problems of education and teaching effectively and efficiently". Thus, supervision activities must be carried out routinely so that there will continue to be improvements in the world of education [3]. The author explain that "the aim of supervision is to help teachers develop their ability to achieve the learning goals that students must achieve. namely by increasing the knowledge and skills of teaching teachers, increasing commitment, and willingness and motivation of teachers, because by increasing the ability and motivation of teacher work, the quality of learning will increase".

The main purpose of supervision is to help teachers develop abilities and creativity in achieving learning goals. The purpose of supervision according to Lia Yuliana [3] are: 1) The final goal is to achieve growth and development of students (which are total). Thus at the same time it will be able to improve society. 2) The second objective is to help the principal in adjusting the education program from time to time continuously in order to face the challenges of changing times. 3) The immediate goal is to work together to develop an appropriate teaching and learning process. 4) The purpose of mediation is to foster teachers so that they can educate students well, or enforce human work discipline. Broadly speaking, the goal of supervision is to foster each other and improve the quality of education by developing creativity in the learning process.

There are several supervision techniques that are deemed necessary and useful to stimulate and direct the attention of teachers to the curriculum and teaching, to identify problems related to teaching and learning. Meanwhile the [5] mentions "some supervision techniques are class visits, individual talks, group discussions, teaching demonstrations, class visits between teachers, curriculum development, supervision bulletins, professional libraries, workshops and community surveys". Principal competencies are needed so that some supervision techniques can be used by school principals to improve teacher performance in facing the digital era. Whereas the mentions several supervision techniques that can be used 
by educator supervisors, including: planned class visits, private meetings between supervisors and teachers, meetings between supervisors and teachers at school, inter-class and inter-school visits, then meetings in the supervising working group, the principal work group and the teacher working group [1].

Supervision techniques in the form of class visits planned to be able to get a picture of learning activities in class. Techniques for supervising personal meetings between supervisors and teachers to discuss specific problems faced by teachers. The technique of supervising meetings between supervisors and teachers in schools, usually to discuss general issues relating to the improvement and or improvement of the quality of education. The technique of supervising visits between classes or between schools is an activity primarily to exchange experiences of fellow teachers or principals about efforts to improve the learning process. Meetings in the supervising working groups, school principals working groups, as well as teacher working group meetings, teacher activity centers and so on. The meetings can be held by each working group, or a combination that is primarily intended to find problems, find alternative solutions, and apply appropriate problem alternatives. Based on the results of preliminary observations at school, several facts were found that supervision at the school had not been able to run optimally. Supervision is carried out by the principal to the teacher only 2 times in one year. Based on the facts above, the assistance in the form of professional supervision by the supervisor of the education staff unit is certainly directed at efforts to improve the implementation of the principal's activities in neutralizing, identifying and finding opportunities that can be created to improve the overall quality of the institution. Academic supervision is very important in evaluating the performance of teachers in the learning process, because teachers are the spearhead of the quality of education. But not only that, the supervision technique used is also needed to improve the creativity of teachers in dealing with the digital age.

\section{Teacher Profile on 21st Century Learning}

The teacher is the oldest profession in the world as long as human existence. When you see community life that is increasingly differentiated and when everyone has many choices as the field of his life, the image of the teaching profession is increasingly declining in social life. Moreover, society is increasingly directed towards materialistic life, so that a profession is valued according to material values. Therefore, it is not surprising that the teaching profession is marginalized and becomes the last choice.

The phenomenon of the ousting of the teaching profession in public life is a global phenomenon. Not only in developed countries, the image of the teaching profession has declined, but also occurs in poor and developing countries. However, there are no classes of people who do not need the teaching profession. It cannot be denied that a society without the teaching profession cannot possibly create a superior, creative and intelligent generation. The irony is that there is so much teacher services in building the nation's community but the awards given are low.

Conceptually, teachers as professional staff must meet various competency requirements to carry out their duties and authorities in a professional manner, while the real conditions in the field are still very alarming, both in quantity, quality and professionalism of [6]. This problem is still compounded by various challenges ahead that are still complex in this global era. From the point of view of the process of learning the development and change of society, as stated Riel Miller quoted by Dwi et al. [5], the community can be divided into three, namely the agricultural community, industrial society and learning society. 
In the era of learning society, marked by rapid progress in the field of information technology, teacher dominance has diminished; the role of technology becomes increasingly high in shaping a conducive learning environment [7]. The era of learning society has enabled students to learn various kinds of knowledge anytime and anywhere without being limited by space and time. Students can access through the internet media, without the presence of the teacher in front of him. So that a teacher may be left behind by his students, when the teacher does not always update his knowledge. So the question becomes, what is the role of the teacher in this era of learning in the 21 st century?

Today's society has changed so quickly that it has an impact on the learning process of the 'modern' generation. This change is driven by developments in information and communication technology. Therefore, for teachers to continue to play a role in the era of $21 \mathrm{st}$ century society, they must be able to transform themselves. Teachers are required to be able to pour their learning in the form of electronic books, or in the form of interactive, interesting and quality animations, so that they can be accessed by their students.

The results of research conducted by Sulisworo et al. [8] in his journal concluded, the use of physics learning media with e-learning. based on Edmodo Blog Education on the subject matter of Optical Devices, is very powerful for use in learning physics, with the percentage of results of media validation by media experts and physics teachers, from the eight components a value of $85.95 \%$ was obtained. The use of physics learning media with e-learning based Edmodo Blog Education on the subject matter of Optical Devices, makes students strongly motivated to learn physics with a percentage of agreed response indicators of $70 \%$; as well as the use of physics learning media with e-learning based on Edmodo Blog Education on the subject matter of Optical Devices can help students to improve student learning outcomes in cognitive aspects.

If the use of ICT in learning still makes students remain passive, reproducing knowledge, then the technology is uselessly integrated in the learning process carried out by the teacher. In the Inside Book of Professional Teachers [7] stated that theoretically the integration ICT in real learning must enable the learning process that:

a. Active: allows students to be actively involved by the existence of interesting and meaningful learning processes.

b. Constructive: allows students to incorporate new ideas into prior knowledge to understand the meaning or curiosity and doubts that have existed in their minds.

c. Collaborative: allows students in a group to work together.

d. Enthusiastic: allows students to actively enthusiastically strive to achieve the desired goals.

e. Dialogical: allows the learning process of students to interact with each other both inside and outside the classroom.

f. Contextual: allows learning situations in a meaningful learning process.

g. High order thinking skills training: makes it possible to practice higher order thinking skills.

h. Therein lies the difference between 21 st century teachers and traditional teachers. 21st century teachers must be able to shift the paradigm of learning from teacher-centered learning, towards student-centered learning. 


\section{Research Method}

This research is to find out the implementation of academic supervision techniques used in a school institution to face the digital era. This study uses descriptive qualitative research methods, namely research procedures that produce descriptive data in the form of written or oral words from respondents or people whose behavior is observed. This study describes various matters relating to the focus of the issues raised. Data collected through observation and interviews. This research was conducted at SMP Negeri 1 Penombeian Panei Simalungun Regency by involving school principals and teachers as the main source of research. When the study was conducted on September 2019.

\section{Results and Discussion}

\subsection{Implementation of Academic Supervision Techniques}

Principal of SMP Negeri 1 Penombeian Panei, Simalungun Regency uses the technique of academic supervision, which is a class visit technique. The principal observes learning activities in class. The class visit technique is carried out in the second and fifth months of each semester. Academic supervision activities from the school principal were conducted twice each semester, and there were 3 stages in each cycle. Namely the supervision phase of learning program planning in the first and fourth months of each semester. Then the second stage is direct observation in the second and fifth months of each semester. And personal meeting techniques are carried out every third and sixth month of each semester.

\subsection{Academic Supervision Techniques Class Visits}

In academic supervision technical activities in the form of class visits, namely planned observations made by the school principal. This technique is always used by principals in carrying out academic supervision of teaching staff. During class visits the principal observes learning activities in the classroom. The principal observes the learning activities, weaknesses and strengths of the learning activities. The principal observes the creativity of teachers in the use of media, models and learning methods. To face the digital era in the 21 st century teachers are required to innovate and be creative in every learning activity. Teachers are also required to use a scientific approach and also problem-based learning and problem based learning, so that students are able to think critically.

\subsection{Academic Supervision Techniques}

Personal Meeting in the academic supervision technical activity in the form of a private meeting in which the principal meets personally with the teaching staff / teacher in a room. This activity aims to exchange experiences, provide input after observing the learning process. The principal also provides guidance to educators / teachers in order to be able to use media, models and learning methods to the maximum. The school principal also provides motivation and support for educators / teachers to always update their knowledge to face the challenges of education in the digital age by attending seminars and workshops.

\subsection{Academic Supervision Techniques Meetings between Supervisors and Teachers in Schools}

In the academic supervision technical activity in the form of a meeting between the supervisor and the teachers, namely the principal held a meeting with the teaching staff/teachers in the school. This activity is carried out to discuss problems in the world of 
education and also within the scope of institutions that are of an improvement nature and also improve the quality of education and the quality of graduates to face the digital era.

One effort to improve teacher professionalism is through teaching supervision. The implementation of teaching supervision needs to be done systematically by the school principal and school supervisors aiming to provide guidance to teachers so that they can carry out their duties effectively and efficiently. In its implementation, both school principals and supervisors use observation sheets containing aspects that need to be considered in improving teacher performance and school performance. To supervise teachers, observation sheets are used in the form of teacher ability assessment tools, whereas to supervise school performance is done by pay close attention to academics, student affairs, personnel, finance, facilities and infrastructure, and public relations. Implementation of the teacher's professional abilities requires teachers to be able to increase their roles, both as informants, organizers, motivators, directors, initiators (initiators of initiatives), transmitter (successor), facilitator, mediator, and evaluator so that they are expected to be able to develop their competence.

Creating an ideal condition where the professional abilities of teachers can be implemented in line with the implementation of regional autonomy, is not an easy thing. This is because the actualization of the ability of teachers depends on various components of the collaborative education system. Therefore, the interrelation of various components of education will determine the implementation of teacher's ability to be able to manage effective learning, in line with the learning paradigm recommended by UNESCO [9], "learning to know, learning to do, learning to live together, and learning to be".

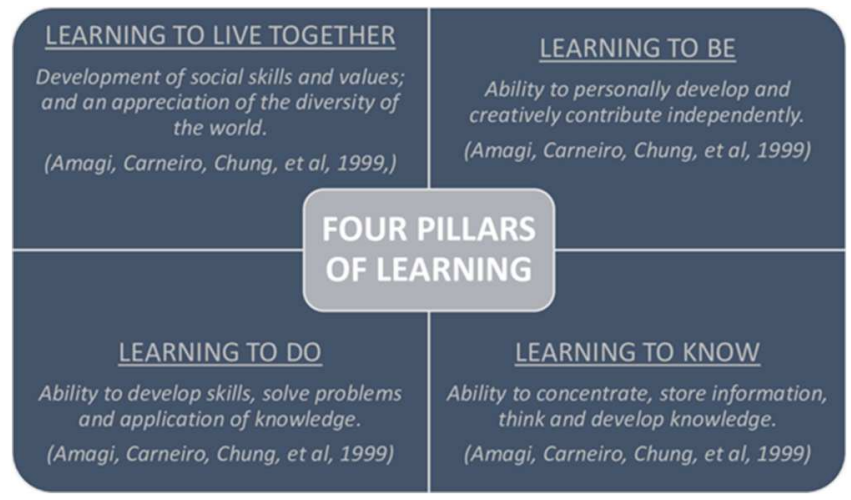

Figure 1. Four Pillars of Learning Explaining Concept by UNESCO

\section{Conclusion}

The conclusion of this article is the implementation of academic supervision techniques conducted by school principals to educators in SMP Negeri 1 PenombeianPanei, Simalungun Regency, namely using academic supervision techniques of class visits, personal meetings and meetings between supervisors and teachers at school. Of the three academic supervision techniques, everything is done by the principal to face the challenges of education in the digital age. Good competency of the principal is needed so that supervision activities can run well and also really improve and improve the quality of education. The principal as a supervisor also provides services in the form of guidance to educators / teachers who are less capable in using media, models and learning methods so that learning is more enjoyable and 
meaningful. The principal also emphasizes problem solving based learning and problem based learning so that students are able to think critically in dealing with problems.

\section{References}

[1] M. Stemm and R. H. Katz, (1997), Measuring and Reducing Energy Consumption Of Network Interfaces In Hand-Held Devices, IEICE Transactions On Communications, v. E80-B (8), pp.1125-1131.

[2] Ari Sudibjo, Wasis, (2013), Penggunaan Media Pembelajaran Fisika Dengan ELearning Berbasis Edmodo Blog Education Pada Materi Alat Optik Untuk Meningkatkan Respons Motivasi Dan Hasil Belajar Siswa Di Smp Negeri 4 Surabaya.

[3] Sutamto. (2019), Tantangan Guru pada Abad Ke-21, (Online), sutamto.wordpress.com.

[4] Lia Yuliana, (2009), PelaksanaanSupervisi Pendidikan Oleh Pengawas Di Sekolah Dasar Se-Kecamatan Gondokusum Yogyakarta.

[5] Dwi, Esti, Andriani, (2010), MengembangkanProfesionalitas Guru Abad 21 Melalui Program Pembimbingan yang Efektif.

[6] Sulisworo, D. (2013), The Paradox on IT Literacy and Science's Learning Achievement in Secondary School. International Journal of Evaluation and Research in Education (IJERE), 2(4), pp.149-152.

[7] Sulisworo, D. (2016). The Contribution of the Education System Quality to Improve the Nation's Competitiveness of Indonesia. Journal of Education and Learning (EduLearn), 10(2), pp.127-138.

[8] Sulisworo, D., Nasir, R., \& Maryani, (2017), Identification of Teachers' Problems in Indonesia on Facing Global Community. International Journal of Research Studies in Education, 6(2), pp.81- 90.

[9] Sulisworo, D., \&Toifur, M. The Role of Mobile Learning on The Learning Environment Shifting at High School InIndonesia. International Journal of Mobile Learning and Organization, (2016), 10(3), pp.159-170. 